\title{
EFFECT OF SOWING DATES AND SULPHUR LEVELS ON SOME SESAME (SESAMUM INDICUM L.) CULTIVARS UNDER NEW VALLEY CONDITIONS
}

\section{Salem, Emad M.M.}

Plant Production Department, Ecology and Dryland Agriculture Division, Desert Research Center, Cairo, Egypt

E-mail: emadmms@yahoo.com<smiles>[V]</smiles>
ield and quality of sesame may be improved by manipulating the cultural practices to suit the crop with the prevailing environment. Therefore, two field experiments were carried out in the Desert Research Center, Agriculture Experimental Station at El-Kharga Oasis, New Valley Governorate, Egypt during 2010 and 2011 growing seasons, to study the response of three Egyptian cultivars of sesame (Shandaweel-3, Toshka-1 and Giza-32) to four sowing dates $\left(15^{\text {th }}\right.$ March, $1^{\text {st }}$ April, $15^{\text {th }}$ April and $1^{\text {st }}$ May) under four levels of sulphur $(0,100,200$ and $300 \mathrm{~kg} \mathrm{~S} / \mathrm{fed})$. The obtained results indicated that planting sesame plants on $15^{\text {th }}$ March (early sowing date) was the superior treatment recorded the highest values of yields, yield components and oil percentage. Shandaweel-3 cultivar gave the highest values of number and weight of capsules per plant, seeds weight per plant, 1000 seeds weight and seed, biological and sesame oil yield/fed. Fruiting zone length, branches and capsules number per plant and biological and seed yields/fed were increased up to $200 \mathrm{~kg} \mathrm{~S} / \mathrm{fed}$. It is evident from the obtained results that planting Shandaweel-3 cultivar on $15^{\text {th }}$ March with adding $100 \mathrm{~kg}$ S/fed could be recommended for improving sesame yield under the New Valley conditions.

Keywords: Sesame, planting dates, cultivars, sulphur

New Valley region (located at the Western Desert of Egypt) is one of the most suitable locations with its oasis, weather is hot and dry as well as the cultivation depends mainly on ground water. Moreover, there is a dire need for increasing the production of crop oils due to increasing population nowadays, which created a very wide gap between production and consumption of food oils reaching $97.1 \%$, approximately. 
Sesame is typically a crop of small farmers in the developing countries and is considered as a drought tolerant crop (Jefferson, 2003). Boureima et al. (2011) indicated that sesame is one of the stress-tolerant crops that produces sorts of chemical components, unavailable in other edible oil crops that provide a resistance to oxidative rancidity, and has made sesame well known as queen of oilseed crops. Sesame seed contains about $50 \%$ oil, $25 \%$ protein, $20 \%$ carbohydrate in addition to amounts of vitamins, minerals, antioxidants and all essential amino and fatty acids. Also, seed meal is an excellent high protein (34-50\%) feed for poultry and livestock (Balasubramaniyan and Palaniappan, 2001).

For synchronizing different stages of plant growth with environmental conditions, the appropriate sowing date is considered one of the most important determining factors for obtaining optimum yield. By selecting appropriate sowing date, different stages of plant growth with environmental conditions adapted that increase the efficiency of photosynthesis, thus assimilates stored seeds is desirable (Erhart et al., 2005). Determining the optimum time of sowing, which in turn improves unit land area utilization and selecting a cultivar with a high average yield is a major factor in ensuring a profitable return of sesame (Hamza and Abd ElSalam, 2015). Nath et al. (2000) reported that sesame can be cultivated in sub-optimal conditions, mainly during February to May in summer. Differential response of varieties to sowing dates showed that the yield of sesame was decreased with delay in sowing beyond third week of July (Mahdi et al., 2007).

The low yield could be due to lack of improved cultivars, sensitive to pests, diseases and environmental conditions. Nath et al., (2003) found that temperature and variety affected seed yield variation by 69 and 39\%, respectively. Varietal differences in sesame yield and its components were stated by several researchers. Saudy and Abd El-Momen (2009) found that Shandawel-3 was the potent cultivar for producing the highest values of plant height, capsules and seeds weights/plant as well as biological, seed and oil yields/fed, in Egypt.

The interaction between sowing date and cultivar affected significantly plant height, number of capsules/plant, seed weight/plant and seed yield (Nath et al., 2001 and Ali and Jan, 2014). Ultimately, higher yield can be achieved through suitable cultivars and optimum sowing date.

Sulphur (S) nutrition has a crucial impact in improving the growth and productivity of the oil seeds due to its vital role in protein metabolism. It is required for the synthesis of proteins, vitamins and chlorophyll and also, $\mathrm{S}$ containing amino acids such as cysteine and methionine, which are essential components of proteins (Jamal et al., 2010).

Lack of $S$ causes retardation of terminal growth and root development. S deficiency induces chlorosis in young leaves and decreases seed yield by $45 \%$ (BARI, 2004). S is one of the essential macroelements of 
plant and is regarded as the fourth key element after $\mathrm{N}, \mathrm{P}$ and $\mathrm{K}$ (Lewandowska and Sirko, 2008). In oilseeds, S plays a significant role in the quality and development of seeds. Therefore, crops of oilseeds require a higher quantity of $\mathrm{S}$ for proper growth and development for higher yields (Salwa et al., 2010). The yield parameters like branches/plant, capsules/plant, seeds/capsule and 1000 seeds weight was improved by increased S in sesame (Tiwari et al., 2000; Sarkar and Panik, 2002 and Thakur and Patel, 2004). The response of sesame to $S$ for producing higher yield was up to $40 \mathrm{Kg} / \mathrm{ha}$ according to Nagavani et al. (2001) and Kathiresan (2002) and up to $50 \mathrm{~kg} / \mathrm{ha}$ (Sarkar and Panik, 2002).

Keeping these points, the present study was carried out to determine the optimum sowing date, cultivar and $S$ level and their combinations for higher productivity of sesame under the New Valley conditions in Egypt.

\section{MATERIALS AND METHODS}

\section{Site Description}

A two-year field experiment was carried out in the Desert Research Center (DRC), Agricultural Experimental Station at EL-Kharga Oasis, New Valley Governorate, Egypt, during the two growing seasons of 2010 and 2011. The soil of the site was sandy clay loam containing $2.08 \%$ organic matter, total sulphur of $8.24 \mathrm{ppm}, \mathrm{pH}$ of 8.11 and $\mathrm{EC}$ of $2.31 \mathrm{dS} / \mathrm{m}$. The preceding crop was wheat in both seasons.

\section{Experimental Treatments and Design}

The study aimed to investigate the effect of three factors, i.e. sowing dates $\left(15^{\text {th }}\right.$ March, $1^{\text {st }}$ April, $15^{\text {th }}$ April and $1^{\text {st }}$ May), cultivars (Shandaweel 3, Toshka 1 and Giza 32) and S levels (0, 100, 200 and $300 \mathrm{~kg}$ S/fed applied in the form of agricultural sulphur at sowing).

A split-split plot design with three replicates was used. Whereas, sowing dates were arranged in the main plots, cultivars were distributed in the sub plots, and $\mathrm{S}$ levels occupied the sub-sub plots. The experimental unit area was $10.5 \mathrm{~m}^{2}$ containing five ridges $(3.5 \mathrm{~m}$ length and $60 \mathrm{~cm}$ apart).

Seeds of sesame cultivars were sown in hills, $20 \mathrm{~cm}$ apart at a rate of $3.0 \mathrm{~kg} / \mathrm{fed}, 21$ days after sowing; plants were thinned to secure two plants per hill. Nitrogen fertilizer was added at a rate of $60 \mathrm{~kg} \mathrm{~N} / \mathrm{fed}$ in the form of ammonium sulfate $(20 \% \mathrm{~N})$ at three equal portions, after thinning, before the second and the third irrigation. Phosphorus fertilizer was applied in the form

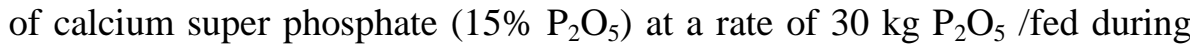
soil preparation. Potassium fertilizer was applied in the form of potassium sulfate $\left(48 \% \mathrm{~K}_{2} \mathrm{O}\right)$ at a rate of $48 \mathrm{~kg} \mathrm{~K} 2 \mathrm{O} / \mathrm{fed}, 75$ days after sowing. Well water was the source for irrigation, $\mathrm{pH}$ of 7.4 and $\mathrm{EC}$ of $1.09 \mathrm{dS} / \mathrm{m}$, was used. Irrigation was applied through gated pipe irrigation system. All other 
recommended agricultural practices were adopted throughout the two experimental seasons.

\section{Sampling and Assessments}

\subsection{Yield traits}

At harvest, ten guarded plants were taken randomly from each plot to measure plant height, fruiting zone length, branches number/plant, number and weight of capsules/plant, 1000 seeds weight and seeds weight/plant. Moreover, whole plants of each plot were collected to measure biological and seeds yield/fed.

\subsection{Seed oil content}

Seed oil percentage was determined by extracting the oil using Soxhlet apparatus with hexane as an organic solvent according to A.O.A.C. (1995), and then oil yield was calculated.

\section{Statistical Methods}

All the obtained data of each season were exposed to the proper statistical analysis of variance, according to Gomez and Gomez (1984). The combined analysis of variance for the data of the two seasons was performed after testing the error homogeneity and least significant difference (LSD) test at 0.05 level of significance was used for the comparison between means.

\section{RESULTS AND DISCUSSION}

\section{Effect of Sowing Dates}

Planting sesame in early sowing date was the potent practice for enhancing all yield, yield attributes and oil percentage of sesame plants (Table 1). In this respect, plant height, fruiting zone length, branches number/plant, number and weight of capsules/plant, seeds weight/plant, weight of 1000 seeds, biological and seeds yield/fed, as well as oil percentage and oil yield were significantly increased with planting sesame on $15^{\text {th }}$ March. The increments in these traits due to the early sowing date surpassed the late one (on $1^{\text {st }}$ May) amounted to 33.9, 47.2, 25.1, 36 and $43.9 \%$ for plant height, weight of capsules/plant, seeds weight/plant, seeds yield/fed and oil yield/fed, respectively. The obtained results show that the adequate environmental growth factors synchronized with the growth stages of sesame planted in early sowing date promoting the growth and yield. Accordingly, the enhancements in sesame yields, yield components and oil percentage with early planting date may be due to that the plants had optimum vegetative growth, adequate photosynthetic activity and more assimilates than planting latter. Bhardwaj et al. (2014) indicated that earlier sowing date resulted in significantly higher seed yield by about $56 \%$. Abdalla et al. (2004) found that flowering and maturity periods were reduced by 18 days due to delayed sowing. Also, the increasing in the yield 
components in early sowing date could be the effect of prolonged photoperiod, which might have resulted in more assimilates in yield components, which have been reflected on yields. The early sowing date as an optimum date for higher yield and its attributes compared to late sowing date in sesame was confirmed by Nath et al. (2001), Abdallah et al. (2004), Tahir et al. (2012), Abarghoui et al. (2015) and Hamza and Abd El-Salam (2015).

\section{Effect of Cultivars}

All yield, yield components and oil percentage were significantly affected by varietal differences among sesame cultivars as shown in table (1). The highest values of plant height, fruiting zone length, branches number/plant and oil percentage were gained from Giza-32 cultivar. On the other hand, Shandaweel- 3 gave the maximum values of number and weight of capsules/plant, seeds weight/plant, 1000 seeds weight and seed, biological and oil yields/fed. Herein, Shandaweel-3 cultivar possessed 44, 17.8, 26.5 and $24.2 \%$ increases in capsules weight/plant, seeds weight/plant and seed and oil yields/fed, respectively compared to Giza-32 cultivar. Such superiority of Shandaweel-3 may be due to the biochemical activity in leaves associating with higher translocation of photosynthetic and sink capacity in addition to its adaptability to environmental stress than other cultivars, which has been reflected on yield components and consequently seed and oil yields. The number of capsules per plant is one of the main components that determine crop yield potentiality; such trait is affected by genetic factors (Ahmad et al., 2002). Our results are in harmony with those obtained by Kassab et al. (2012), Ali and Jan (2014), Hamza and Abd El-Salam (2015) and Mahrous et al. (2015).

\section{Effect of S Levels}

Results in table (1) illustrate that all studied traits of sesame were significantly affected by S levels. In this regard, adding $100 \mathrm{~kg}$ S/fed was the excelsior practice being recorded the maximal values of plant height, capsules and seeds weight/plant, weight of 1000 seeds, oil percentage and oil yield/fed. Potency of such treatment for plant height, capsules weight/plant, seeds weight/plant and oil yield/fed amounted to 12.4, 70.6, 140.5 and $97.7 \%$, respectively, compared to without adding $\mathrm{S}$ treatment. Otherwise, adding $200 \mathrm{~kg} \mathrm{~S} /$ fed possessed the highest values of fruiting zone length, branches and capsules number/plant and biological and seeds yield/fed. The increments due to application of $200 \mathrm{~kg} \mathrm{~S} / \mathrm{fed}$ for biological and seeds yield/fed reached 71.1 and $76.9 \%$, respectively, compared to without adding $\mathrm{S}$ treatment. It is of interest to mention here that adding $200 \mathrm{~kg} \mathrm{~S} / \mathrm{fed}$ achieved the significantly highest values of biological and seeds yield/fed but, statistically at par with those of adding $100 \mathrm{~kg} \mathrm{~S} / \mathrm{fed}$. Moreover, 
increasing S levels up to $300 \mathrm{~kg} \mathrm{~S} / \mathrm{fed}$ resulted in the decrease of all studied traits. The remarkable influence of applied $S$ levels on sesame yields, yield components and oil percentage may be due to the fact that $S$ application improves the soil chemical properties (i.e. decrease the $\mathrm{pH}$ of soil solution) and therefore increases the availability of nutrients. Application of Scontaining fertilizer can result in soil acidification and may eventually influence nutrient uptake (Havlin et al., 2007). Also, Shilpi et al. (2014) found that different levels of S caused significant variation for NPKS uptake by plant of sesame. Additionally, nitrogen and S metabolism are linked to each other. S-deficiency resulted in decrease in nitrate reductase activity and in the accumulation of chlorophyll, amino acid and sugar (Jamal et al., 2009 and Shilpi et al., 2012).

In oil seeds, $S$ plays a significant role in the quality and development of seeds. Therefore, crops of oil seeds require a higher quantity of $S$ for proper growth and development for higher yields (Jamal et al., 2010 and Salwa et al., 2010). Unlike, the excess $S$ application (300 kg S/fed) as shown in table (1) resulted in declined sesame yields and its attributes.

Thus, it can be inferred that adding $100 \mathrm{~kg}$ S/fed was the best treatment for improving and economical applied to enhancing the productivity of sesame plants compared to adding 200 or $300 \mathrm{~kg}$ S/fed. Such results are in full agreement with those obtained by Raja et al. (2007), Shilpi et al. (2012), De et al. (2013), Shah et al. (2013) and Puste et al. (2015).

\section{Effect of Interactions}

First order interactions, i.e. sowing dates $\times$ cultivars; sowing dates $\times$ $\mathrm{S}$ levels and cultivars $\times \mathrm{S}$ levels are presented in tables $(2,3$ and 4 , respectively) as well as the second order one i.e. sowing dates $\times$ cultivars $\times S$ levels is shown in table (5).

\subsection{Sowing dates $\times$ cultivars}

Remarkable influence of the interaction between sowing dates $x$ cultivars on all sesame yields, yield components and oil percentage were obtained, except for weight of 1000 seeds, which was not significantly affected (Table 2). Herein, planting sesame Giza-32 cultivar in 15 March was the most effective practice for increasing plant height, fruiting zone length, branches number/plant and oil percentage. Also, planting Shandaweel-3 cultivar in $15^{\text {th }}$ March was the effective pattern for promoting capsules number and weight/plant, seeds weight/plant and biological seeds and oil yields/fed. These results are in accordance with those obtained by Ali and Jan (2014), Chongdar et al. (2015) and Hamza and Abd El-Salam (2015). The interaction between sowing dates and varieties was also highly significant as found by Hazarika (1998) and Chongdar et al. (2015). 


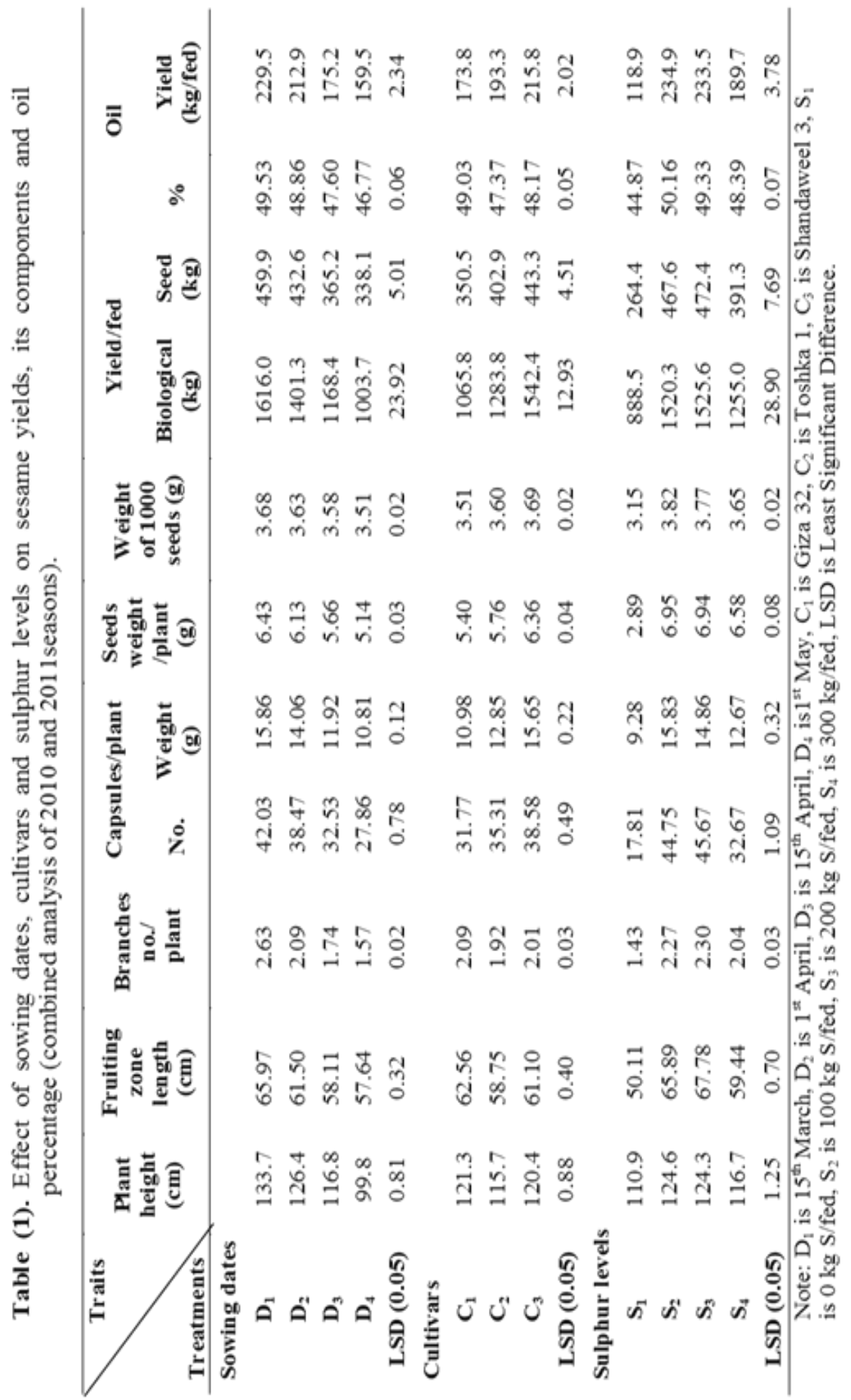

Egyptian J. Desert Res., 66, No. 1, 17-34 (2016) 


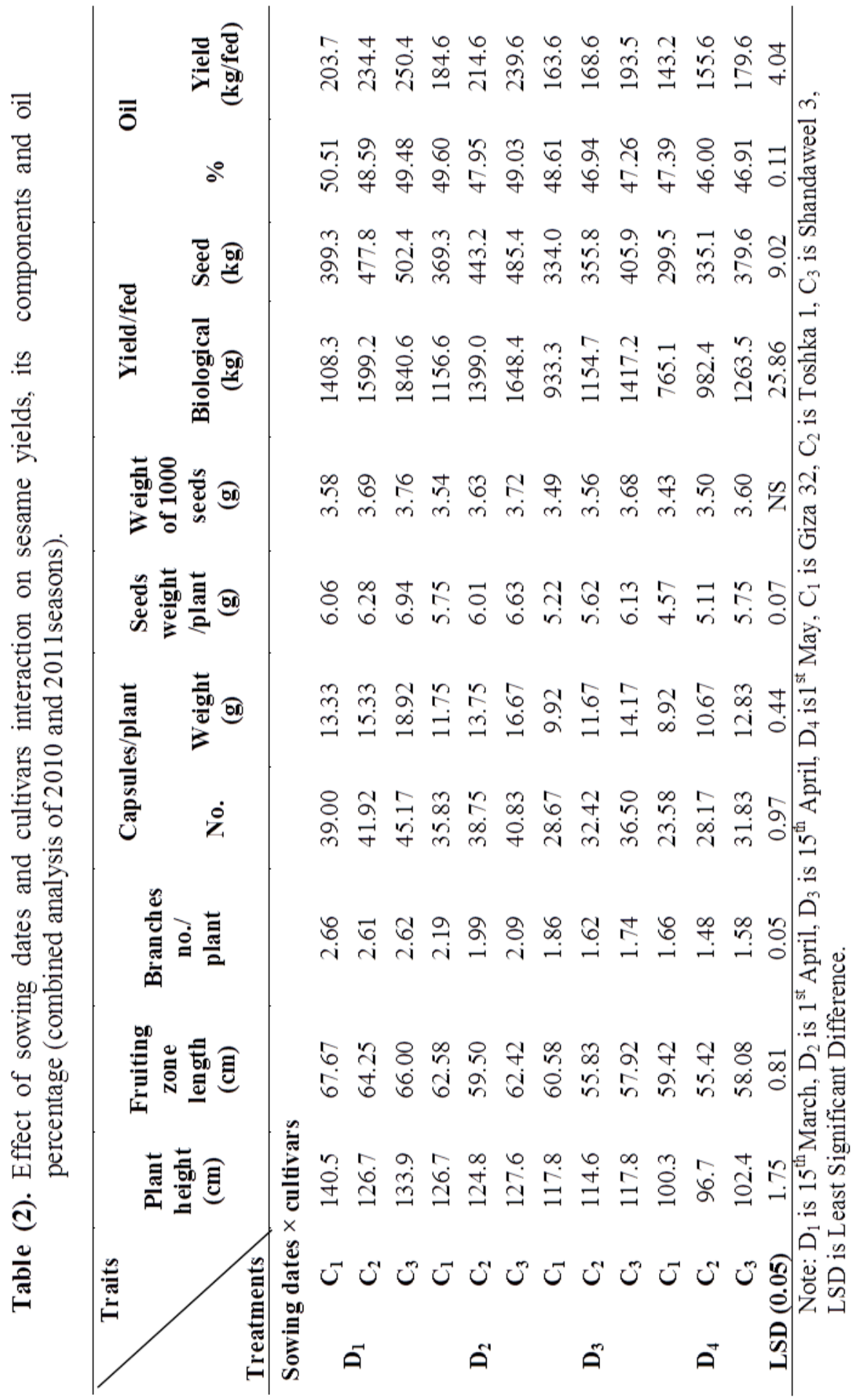

Egyptian J. Desert Res., 66, No. 1, 17-34 (2016) 


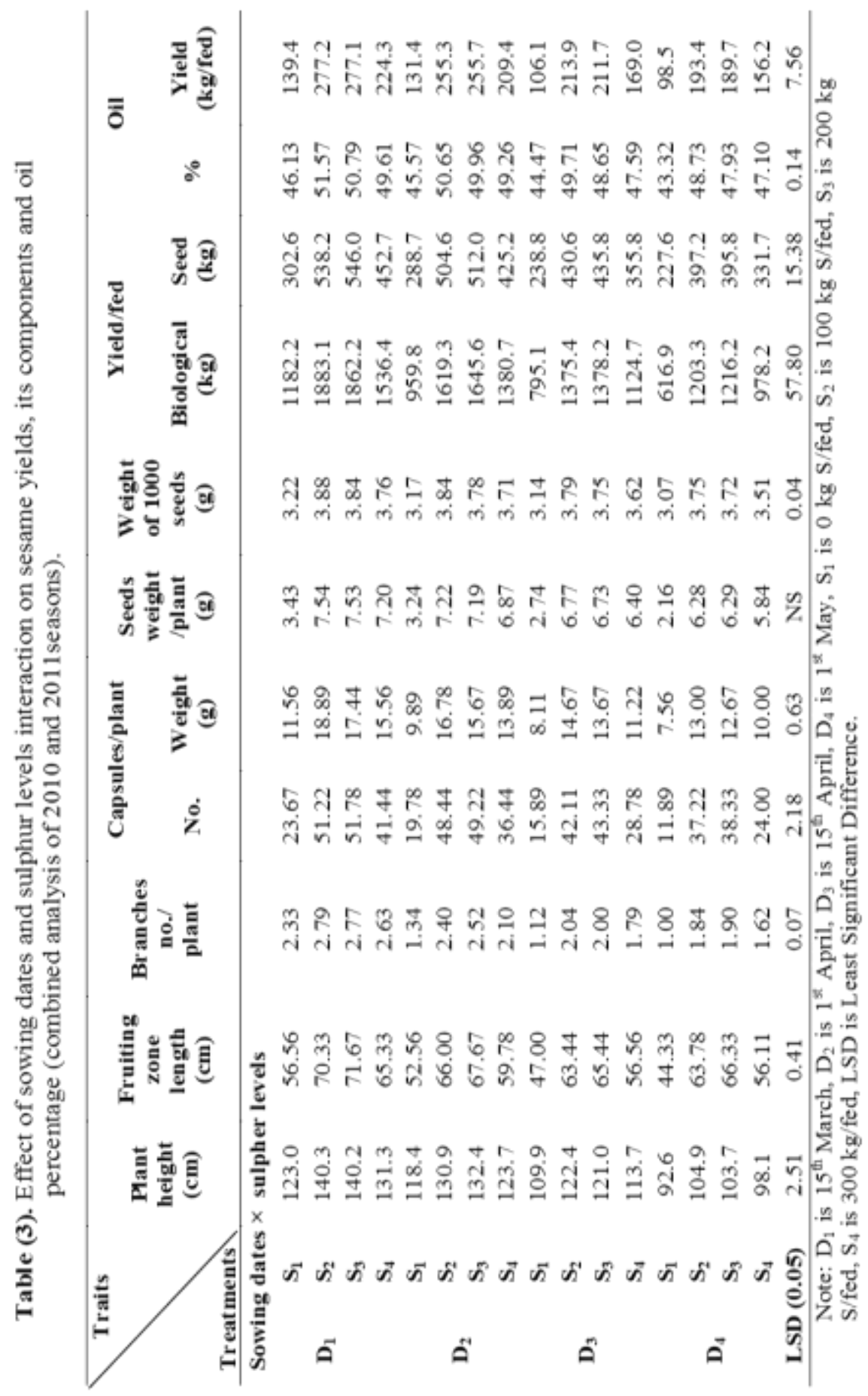

Egyptian J. Desert Res., 66, No. 1, 17-34 (2016) 


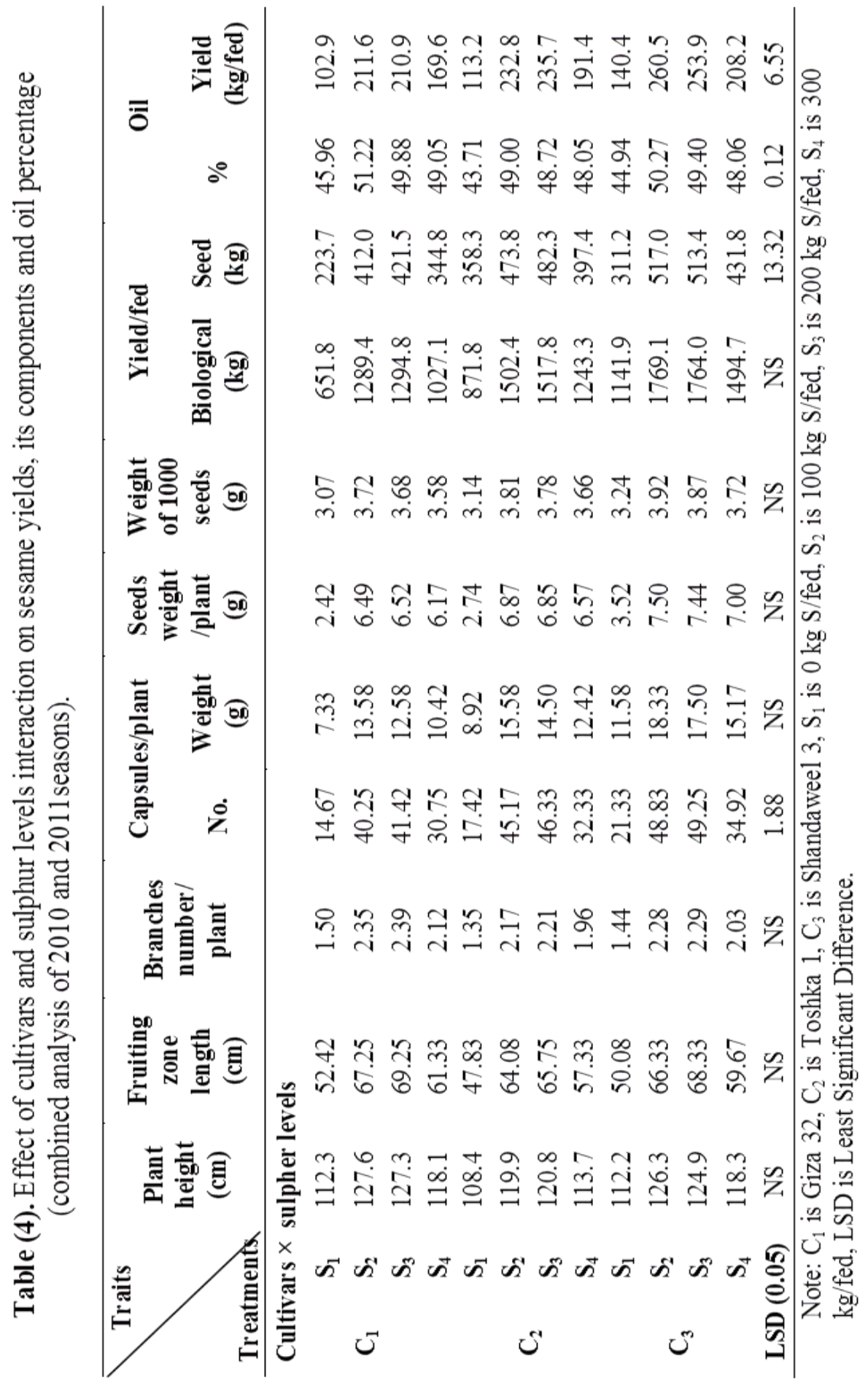

Egyptian J. Desert Res., 66, No. 1, 17-34 (2016) 


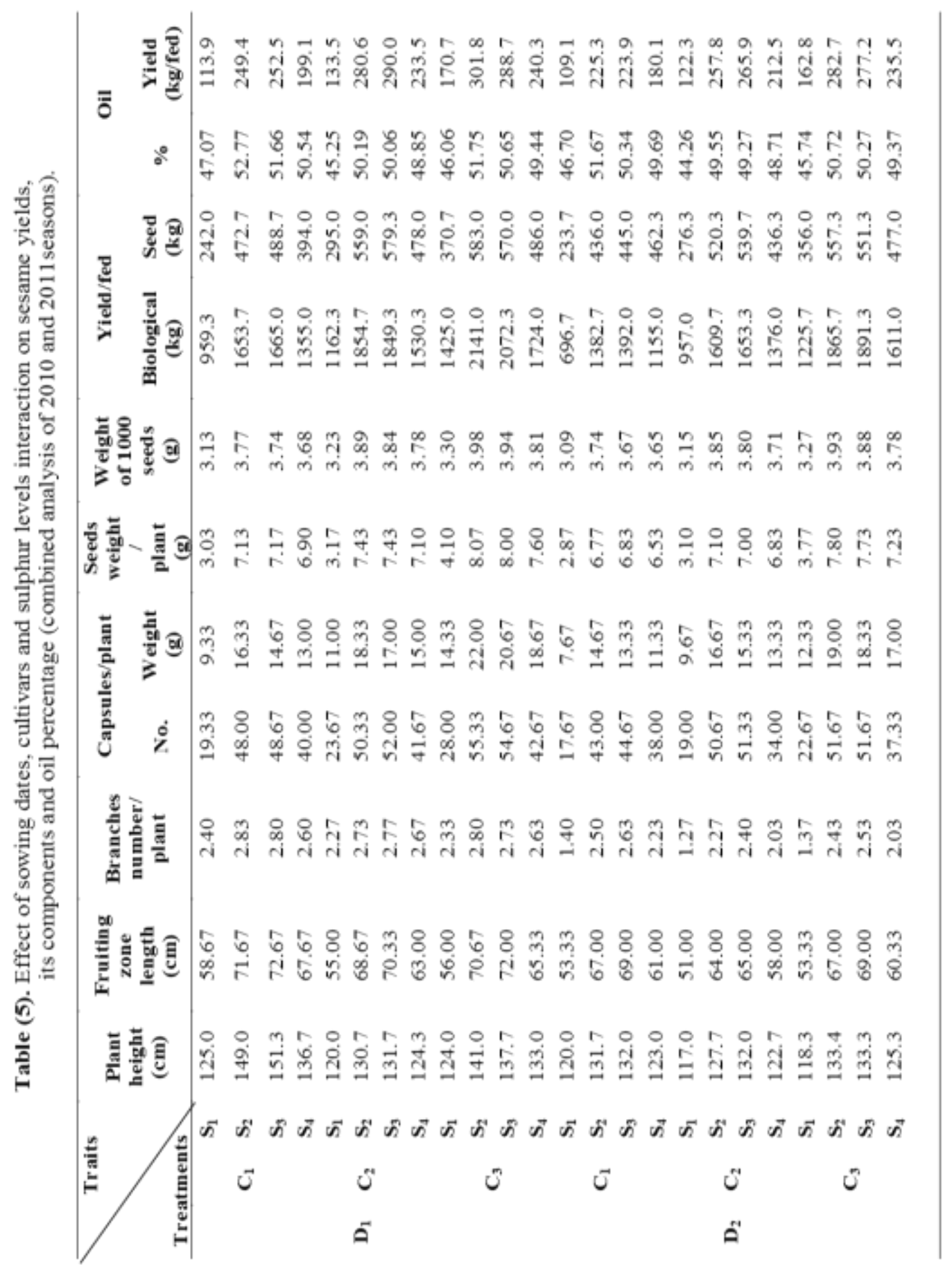

Egyptian J. Desert Res., 66, No. 1, 17-34 (2016) 


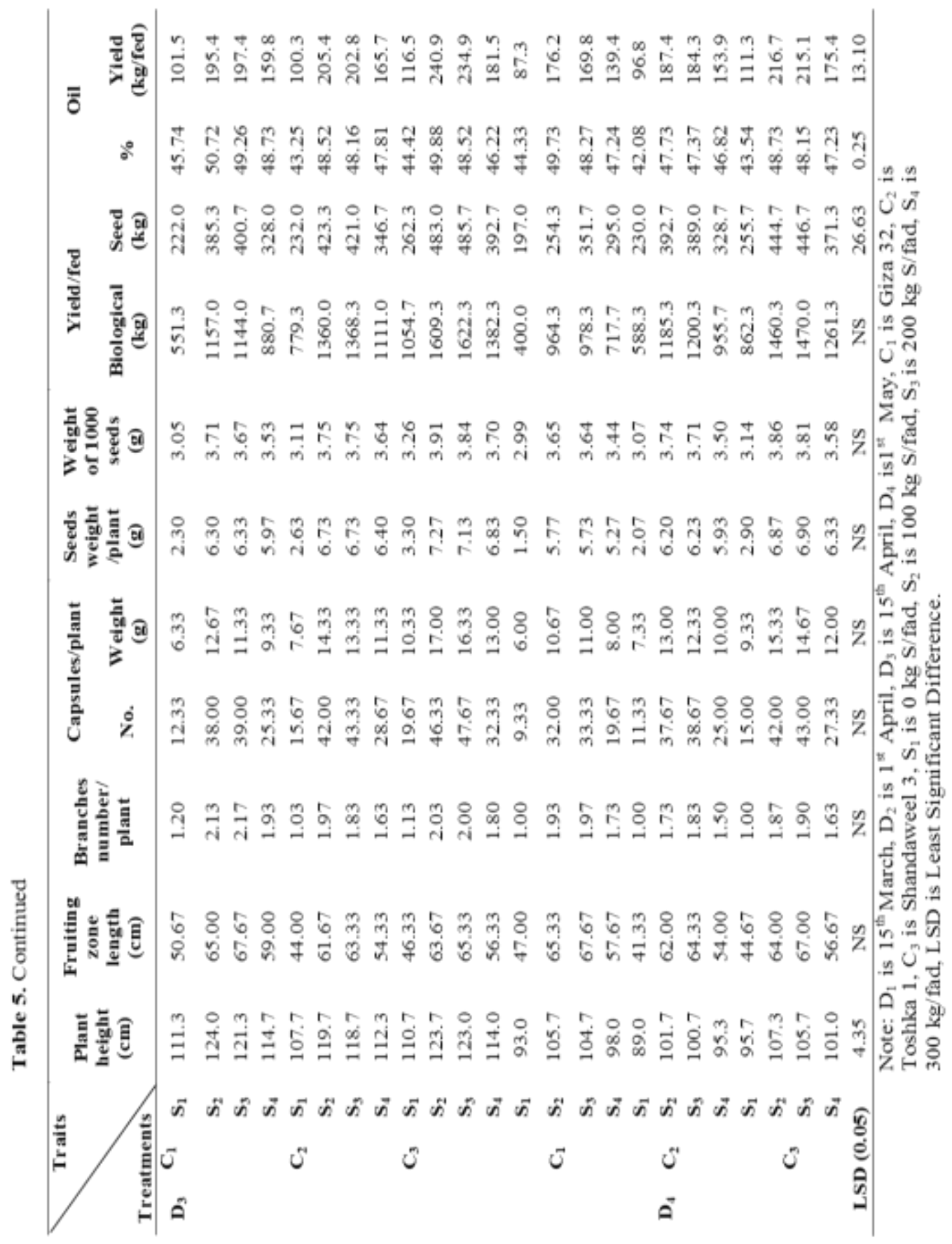

Egyptian J. Desert Res., 66, No. 1, 17-34 (2016) 


\subsection{Sowing dates $\times S$ levels}

With the exception of seeds weight/plant, all sesame yields, yield components and oil percentage were markedly responded to the interaction between sowing dates and S levels (Table 3). In this concern, $15^{\text {th }}$ March (early sowing date) with adding $100 \mathrm{~kg} \mathrm{~S} /$ fed secured the highest values of plant height, branches number/plant, capsules weight/plant, weight of 1000 seeds, biological and oil sesame yields/fed and oil percentage, respectively. In early sowing date, fruiting zone length, capsules number/plant and sesame seed yield/fed showed the maximum increases with adding $200 \mathrm{~kg} \mathrm{~S} / \mathrm{fed}$, but statistically at par with adding $100 \mathrm{~kg} \mathrm{~S} / \mathrm{fed}$ in this respect.

\subsection{Cultivars $\times S$ level}

Shandaweel-3 cultivar plants fertilized with $200 \mathrm{~kg} \mathrm{~S} /$ fed recorded the maximum values of capsules number/plant. While, with the same cultivar, pots received $100 \mathrm{~kg} \mathrm{~S} /$ fed was the most effective for enhancing sesame seed and oil yields/fed (Table 4). Otherwise, Giza-32 cultivar possessed the highest value of oil percentage in plots fertilized with $100 \mathrm{~kg}$ $\mathrm{S} / \mathrm{fed}$. Discriminated response of varieties to $\mathrm{S}$ levels showed that the yield of sesame was increased with adding S up to limited dose (Raja et al., 2007; Mondal et al., 2012 and Shah et al., 2013).

\subsection{Sowing dates $\times$ cultivars $\times S$ levels}

The impact of possible interactions among the three tested factors on sesame yields, yield components and oil percentage are presented in table (5). Early sowing date of $15^{\text {th }}$ March $x$ Shandaweel-3 cultivar $x$ adding 100 $\mathrm{kg}$ S/fed recorded the highest values of sesame seed and oil yields/fed. While, oil percentage gave the maximum increase with the interaction of early sowing date of $15^{\text {th }}$ March $\times$ Giza-32 cultivar $\times$ adding $100 \mathrm{~kg} \mathrm{~S} / \mathrm{fed}$. Whereas, the tallest sesame plants were achieved with combination of early sowing date of $15^{\text {th }}$ March $\times$ Giza-32 cultivar $\times$ adding $200 \mathrm{~kg} \mathrm{~S} / \mathrm{fed}$.

\section{CONCLUSION}

It could be concluded that under the similar conditions of this investigation, early sowing date $\left(15^{\text {th }}\right.$ March) with Shandaweel-3 cultivar and adding $100 \mathrm{~kg}$ S/fed could be recommended for increasing sesame yield and its components.

\section{REFERENCES}

Abarghoui, G.B., A. Koocheki and M.N. Mahalati (2015). Effect of planting date and integrative nitrogen application on quantity and quality yield of sesame (Sesamum indicum L.). GMP Review, 18 (1): 744754. 
Abdalla, A.A., M.O. Mohamed and E.A. Fiasal (2004). Response of Sesame (Sesamum indicum L.) cultivars to sowing date under irrigation. A paper presented in the Crop Husbandry Committee Meeting Jan. ARC, Sudan.

Ahmad, R., M. Tariq, M.F. Seleem and S. Ahmad (2002). Comparative performance of two sesame (Sesamum indicum L.) varieties under different row spacing. Asian J. Plant Sci., 1 (5): 546-547.

Ali, S. and A. Jan (2014). Sowing dates and nitrogen levels effect on yield and yield attributes of sesame cultivars. Sarhad J. Agric., 30 (2): 203-209.

A.O.A.C. (1995). In "Official Methods of Analysis". $16^{\text {th }}$ Association of Official Analytical Chemists, Washington, DC. USA.

Balasubramaniyan, P. and S.P. Palaniappan (2001). In "Field Crops: An Overview". Principles and Practices of Agronomy, Agrobios, India, $47 \mathrm{pp}$.

BARI (Bangladesh Agricultural Research Institute) (2004). Annual Report for 2003. BARI. p. 28.

Bhardwaj, H.L., A.A. Hamama, M.E. Kraemer and D.R. Langham (2014). Cultivars, planting dates and row spacing effects on sesame seed yield and mineral composition. J. of Agric. Sci., 6 (9): 1-7.

Boureima, S., M. Eyletters, M. Diouf,, T.A. Diop and P. Van Damme (2011). Sensitivity of germination and seeding radical growth to drought stress in sesame (Sesamum indicum L.). Res. J. of Environmental Sci., 5 (6): 557-564.

Chongdar, S., A. Singharoy, A. Saha and B. Chhetri (2015). Performance of summer sesame (Sesamum indicum L.) cultivars under varying dates of sowing in prevailing agro-climatic condition of North Bengal. Scientific Research and Essays, 10 (12): 411-420.

De, P.S., V.M. Bhale and V.A. Khadse (2013). Quality and economics of summer sesame (Sesamum indicum L.) as influenced by irrigation and nutrient levels. International Journal of Bio-resource and Stress Management, 4 (2): 369-371.

Erhart, E. W. Hartl and B. Putz (2005). Bio waste compost affects yield, nitrogen supply during the vegetation period and crop quality of agricultural crops. European J. of Agron., 23: 305-314.

Gomez, K.A. and A.A. Gomez (1984). In "Statistical Procedure for Agriculture Research". An International Rice Research Institute Book John Willey and Sons, Inc., New York.

Hamza, M. and R.M. Abd El-Salam (2015). Optimum planting date for three sesame cultivars growing under sandy soil conditions in Egypt. American-Eurasian J. Agric. and Environ. Sci., 15 (5): 868-877.

Havlin, J.L., J.D. Beaton, S.L. Tisdale and W.L. Nelson (2007). In "Soil Fertility and Fertilizers". An introduction to Nutrient Management, $7^{\text {th }}$ edition, Pearson Education Inc., Singapore, $221 \mathrm{pp}$.

Egyptian J. Desert Res., 66, No. 1, 17-34 (2016) 
Hazarika, D.K. (1998). Influence of sowing date and varieties on development of powdery mildew of sesame in Assam. J. Phytological Res., 11: 73-75.

Jamal, A., K. Ko, H.S. Kim, T.K. Cho, H. Joung, and K. Ko (2009). Role of genetic factors and environmental conditions in recombinant protein production for plant molecular biofarming. Biotechnology Advances, 27: 914-923.

Jamal, A.,Y. Moon and M.Z. Abdin (2010). Sulphur- a general over view and interaction with nitrogen. Australian Journal of Crop Science, 4: 523-529.

Jefferson, T. (2003). Sesame a high value oil seed. Growing sesame production: Tips, economics and more, www.Jeffersoninstitute. Org/pubs/sesame. Shtml.

Kassab, O.M., H.M. Mehanna and A. Aboelill (2012). Drought impact on growth and yield of some sesame varieties. Journal of Applied Sciences Research, 8 (8): 4544-4551.

Kathiresan (2002). Response of sesame genotypes to levels of nutrient and spacing under different season. Indian J. Agron., 47: 537-540.

Lewandowska, M. and A. Sirko (2008). Recent advances in understanding plant response to sulphur deficiency stress. Acta Biochimica. Polonica, 55: 457-471.

Mahdi, A., S.E.M. Amin and F.G. Ahmed (2007). Effect of sowing date on the performance of sesame (Sesamum indicum L.) genotypes under irrigation conditions in Northern Sudan. African Crop Sciences Conference Proceedings, 8: 1943-1946.

Mahrous, N.M., N.M. Abu-Hagaza, H.H. Abotaleb and Salwa M.K. Fakhry (2015). Enhancement of growth and yield productivity of sesame plants by application of some biological treatments. AmericanEurasian J. Agric. and Environ. Sci., 15 (5): 903-912.

Mondal, M.M.A., M. Badruddin, M.A. Malek, M.B. Hossain and A.B. Puteh (2012). Optimization of sulphur requirement to sesame (Sesamum indicum L.) genotypes using tracer techniques. Bangladesh J. Bot., 41 (1): 7-13.

Nagavani, A.V., V. Sumathi, V. Chandrika and M.A. Babu (2001). Effect of nitrogen and sulphur on yield and oil content of sesame. J. Oil Seeds Res., 18: 73-77.

Nath, R., P.K. Chakraborty and A. Chakraborty (2000). Effect of micro climatic parameters at different sowing dates on capsule production of sesame (Sesamum indicum L.) in a tropical humid region. J. Agron. Crop Sci., 184: 247-252.

Nath, R., P.K. Chakraborty and A. Chakraborty (2001). Effect of climatic variation on yield of sesame (Sesamum indicum L.) at different dates of sowing. J. Agron. Crop Sci., 186: 97-102. 
Nath, R., P. Chakraborty, P. Bandopadhyay, C. Kunduand and A. Chakraborty (2003). Analysis of relationship between crop growth parameters, yield and physical environment within the crop canopy of sesame (Sesamum indicum L.) at different sowing dates. Archives Agron. Soil Sci., 49: 677-682.

Puste, A.M., B. Ray Pramanik, K. Jana, S. Roy and T. Sunanda Devi (2015). Effect of irrigation and sulphur on growth, yield and water use of summer sesame (Sesamum indicum L.) in New Alluvial Zone of West Bengal. Journal Crop and Weed., 11 (Special Issue): 106-112.

Raja, A., K.O. Hattab, L.Gurusamy, G. Vembu and S. Suganya (2007b). Sulphur application on growth and yield and quality of sesame varieties. Int. J. Agric. Res., 2: 599-606.

Salwa, A.I.E., M.A. Mohsen and S.S. Behary (2010). Amelioration productivity of sandy soil by using amino acid, sulphur and micronutrients for sesame production. American Journal of Science, 6: 250-257.

Sarkar and Panik (2002). Effect of planting geometry direction of planting and sulphur application on growth and productivity of sesame. Indian J. Agric. Sci., 72: 70-73.

Saudy, H.S. and W.R. Abd-El-Momen (2009). Cultural and manual weed management in sesame. J. Agric. Sci. Mansoura Univ., 34 (8): 90019013.

Shah, M.A., A. Manal, M. Hussain, S. Farooq and M. Zafar-Ul-Hye (2013). Sulphur fertilization improves the sesame productivity and economic returns under rainfed conditions. Int. J. of Agric. and Biology, 15 (6): 1301-1306.

Shilpi, S., M.N. Islam, G.N.C. Sutradhar, A. Husna and F. Akter (2012). Effect of nitrogen and sulphur on the growth and yield of sesame. International Journal of Bio-resource and Stress Management, 3 (2): 177-182.

Shilpi, S., M.D. Nuruzzaman, Fahmina Akhter, M.N. Islam and G.N.C. Sutradhar (2014). Response of nitrogen and sulphur on the oil content of sesame and nutrient status of soil. International Journal of Bio-resource and Stress Management, 5 (1): 041-046.

Tahir, M., U. Saeed, A. Ali, I. Hassan, M. Naeem, M. Ibrahim, H.U. Rehman and H.M.R. Javeed (2012). Optimizing sowing date and row spacing for Newly Evolved sesame (Sesamum indicum L.) variety TH-6. Pak. J. Life Soc. Sci., 10 (1):1-4.

Thakur, D.S. and S.R. Patel (2004). Response of sesame (Sesamum indicum L.) to different levels of potassium and sulphur in light-textured inceptisols of Eastern part of Chhattisgarh. Ind. J. Agric. Sci., 74: 496-498.

Egyptian J. Desert Res., 66, No. 1, 17-34 (2016) 
Tiwari, R.C., K. Namdeo and K.N. Girisha (2000). Effect of nitrogen and sulphur on growth, yield and quality of sesame varieties. Res. Crops, 1: $163-167$.

Received: 3/3/2016

Accepted: 16/6/2016 


\section{تأثير مواعيد الزراعة ومستويات الكبريت على بعض أصناف السمسم تحت ظروف الوادي الجديد}

عماد محمل محمل سالم

قسم الإنتاج النباتي، شعبة البيئة وزراعات المناطق الجافة، مركز بحوث الصحر اء، القاهرة،

مصر

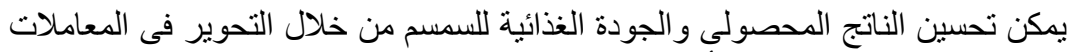

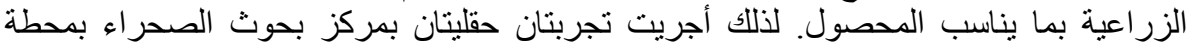

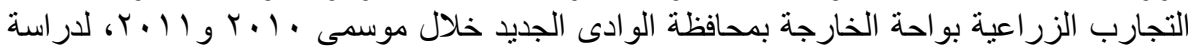

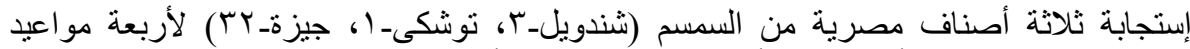

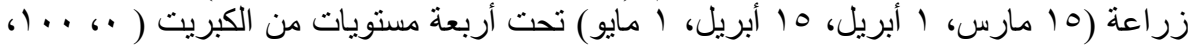

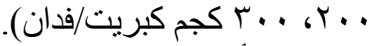

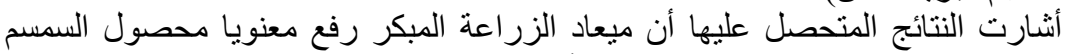

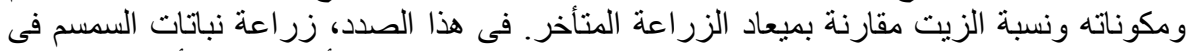

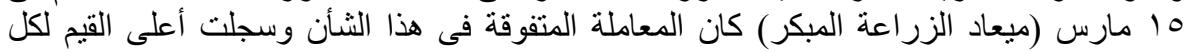

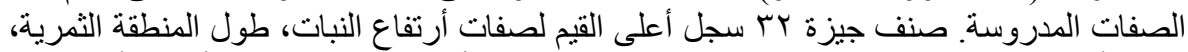

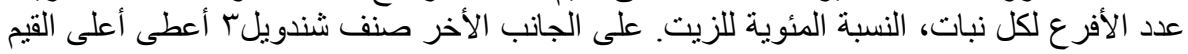

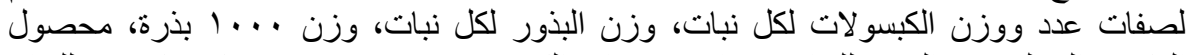

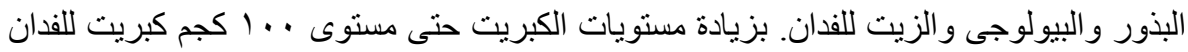

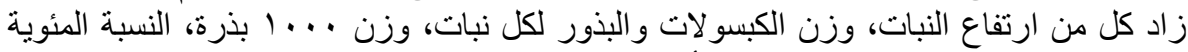

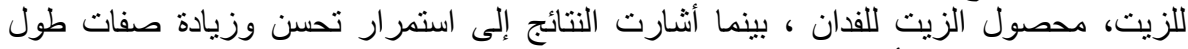

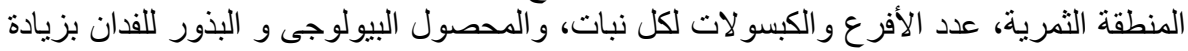

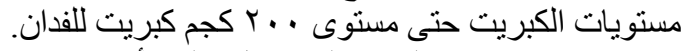

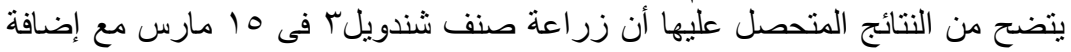

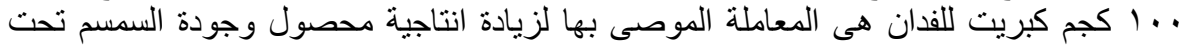

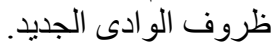

Egyptian J. Desert Res., 66, No. 1, 17-34 (2016) 